\title{
PERAN MOTIVASI KERJA MEMEDIASI PENGARUH PENGEMBANGAN KARIR TERHADAP KINERJA KARYAWAN BPR LESTARI CABANG SESETAN DENPASAR
}

\author{
Ni Putu Ade Intan Sesi ${ }^{1}$ \\ I Gusti Made Suwandana ${ }^{2}$ \\ ${ }^{1,2}$ Fakultas Ekonomi Dan Bisnis Universitas Udayana (Unud), Bali, Indonesia \\ email: adeintansesi@gmail.com
}

\begin{abstract}
ABSTRAK
Tujuan penelitian ini adalah untuk mengetahui pengaruh pengembangan karir terhadap kinerja karyawan melalui mediasi motivasi kerja. Penelitian ini dilakukan di BPR Lestari Cabang Sesetan Denpasar jumlah sampel yang diambil sebanyak 74 orang karyawan, dengan metode yang digunakan adalah sampel jenuh. Pengumpulan data diperoleh dari hasil wawancara dan penyebaran kusioner. Teknik analisis data yang digunakan adalah uji asumsi klasik, analisis jalur (path analysis), uji sobel dan uji VAF. Berdasarkan hasil analisis ditemukan bahwa Pengembangan karir berpengaruh positif dan signifikan terhadap motivasi kerja karyawan. Pengembangan karir berpengaruh positif dan signifikan terhadap kinerja karyawan. Motivasi kerja berpengaruh positif dan signifikan terhadap kinerja karyawan. Motivasi kerja berpengaruh positif dan signifikan dalam memediasi hubungan antara pengembangan karir terhadap kinerja karyawan.
\end{abstract}

Kata kunci : kinerja karyawan, motivasi kerja, pengebangan karir

\begin{abstract}
The purpose of this study was to study the motivation for developing employees through mediating work motivation. This research was conducted at BPR Lestari Sesetan Branch Denpasar with a total sample of 74 employees, with the method used was a saturated sample. Data collection was obtained from interviews and questionnaires. Data analysis techniques used are the classic assumption test, path analysis (path analysis), single test and VAF test. Based on the results of the analysis found about positive and significant career development on employee work motivation. Positive and significant career development on employee performance. Positive and significant work motivation on employee performance. Positive and significant work motivation in mediating the relationship between career development and employee performance.
\end{abstract}

Keywords: employee performance, work motivation, career dismissal 


\section{PENDAHULUAN}

Segala aspek kehidupan di tuntut untuk bersaing menjadi yang terbaik, karena yang terbaiklah yang akan menguasai pasar dalam era globalisasi saat ini. Perusahaan di tuntut dalam menghadapi era persaingan bisnis yang semakin ketat Perkembangan dunia Industri dalam bisnis menyebabkan persaingan semakin kompleks sehingga perusahaan harus memperhatikan pemanfaatnya agar memberikan keuntungan dan efisiensi sehingga tujuan perusahaan dapat tercapai.Industri perbankan yang bergerak dibidang jasa keuangan yang memberipelayanan yaitu mengambil dana berupa produk tabungan, deposito, dan menyalurkan dana dan memeberikan jasa bank lainnya.

Perbankan yang merupakan bisnis jasa saat ini berada dalam persaingan yang sangat ketat.salah satu cara mengatasi masalah tersebut yaitu sumber daya manusia dalam hal ini memiliki peran yang besar agar tujuan dari perusahaan itu dapat tercapai, oleh karena itu kinerja yang dimiliki karyawan harus terus ditingkatan, agar perusahaan dapat bersaing dan mampu memberikan pelayanan yang baik kepada nasabah. Kinerja menjadi salah satu komponen yang sangat penting bagi manajemen untuk melakukan evaluasi dalam pencapaian tujuan perusahaan dan perencanaan di masa depan.

Shahzadi et al. (2014) menyatakan bahwa kinerja karyawan melibatkan kualitas dan kuantitas output, kehadiran ditempat kerja dan ketepatan waktu dalam menyelesaikan tugas (Hakim, 2014). Seorang karyawan dikatakan berhasil melaksanakan pekerjaannya atau memiliki kinerja baik, apabila hasil kerja yang diperoleh lebih tinggi dari standar kinerja. Faktor yang diduga mempengaruhi kinerja karyawan adalah motivasi kerja (Nurcahyani \& Adnyani, 2016). Berarti motivasi kerja karyawan sangat dibutuhkan guna meningkatkan kinerja pegawai. Veronica et al. (2018) mengemukakan motivasi kerja merupakan dorongan, upaya dan keinginan yang ada dalam diri manusia yang mengaktifkan, memberi daya, serta mengarahkan perilaku untuk melaksanakan tugas-tugas dengan baik dalam lingkup pekerjaanya.

Caroline \& Susan (2015) menyatakan bahwa seorang pemimpin yang mengharapkan pencapaian kinerja maksimal di organisasi harus memperhatikan faktor-faktor yang mempengaruhi kinerja pegawai sendiri adalah pengembangan karir (career development). Pengembangan karir merupakan pendekatan formal yang dilakukan organisasi untuk menjamin orang-orang dalam organisasi mempunyai kualifikasi, kemampuan, dan pengalaman yang cocok ketika di butuhkan (Kaseger, 2013).

Penelitian ini dilakukan di BPR Lestari Cabang Sesetann Denpasar merupakan Bank Perkreditan Rakyat yang hanya diperbolehkan menjalankan aktivitas perbankan secara konvensional yaitu mengambil dana dari masyarakat berupa produk tabungan dan deposito, dan menyalurkan kembali dananya kepada masyarakat berupa kredit. BPR Lestari berlokasi di Jalan Raya Sesetan no 45 Denpasar, berdiri sejak tgl 22 Maret 1989. BPR Lestari ini menyediakan berbagai macam jenis Tabungan. BPR Lestari memiliki standar tertinggi dalam pelayanan dan kualitas terhadap nasbah yang datang Ke BPR Lestari.

Berdasarkan hasil wawancara masih ada banyak terdapat penilaian terhadap kinerja karyawan sehingga terdapat beberapa keluhan nasabah terhadap kinerja 
karyawan yang dating ke BPR Lestari Cabang Sesetan Denpasar dapat dilihat di tabel 1. sebagai berikut.

Tabel 1.

Data Keluhan Nasabah di BPR Lestari Bali Enam Bulan Terakhir

\begin{tabular}{ccccc}
\hline & \multicolumn{3}{c}{ Jenis } & Keluhan Nasabah \\
\cline { 2 - 5 } Bulan & $\begin{array}{c}\text { Merchant } \\
\text { (orang) }\end{array}$ & $\begin{array}{c}\text { Gangguan } \\
\text { pada ATM } \\
\text { (orang) }\end{array}$ & $\begin{array}{c}\text { Kurangnya Fasilitas } \\
\text { Tabungan (orang) }\end{array}$ & $\begin{array}{c}\text { Terjadinya gangguan } \\
\text { pada mobile Banking } \\
\text { (orang) }\end{array}$ \\
\hline Januari & 1 & 1 & 3 & 0 \\
Februari & 0 & 4 & 1 & 3 \\
Maret & 2 & 3 & 2 & 1 \\
April & 3 & 2 & 8 & 2 \\
Mei & 2 & 2 & 4 & 3 \\
Juni & 1 & 2 & 2 & 1 \\
Total & 9 & 14 & 20 & 10 \\
\hline Sumber: Data BPR Lestari Bali, 2019 & &
\end{tabular}

Pada Tabel 1. menunjukan keluhan nasabah yang dating ke BPR Lestari berdasarkan keluhan Merchant, Gangguan pada ATM, Kurangnya fasilitas Tabungan, dan terjadinya gangguan pada Mobile Banking. Total keluhan Nasabah selama enam bulan trakhir yaitu sebanyak 53 keluhan nasabah. Dimana keluhan terbesar yaitu kurangnya fasilitas Tabungan. Apabila masalah kinerja tidak ditangani dengan baik akan menyebabkan terganggunya kinerja karyawan yang ada di BPR Lestari. Oleh karena itu perusahaan harus lebih memperhatikan karyawannya, sebeb dalam keluhan nasabah merupakan salah satu sacara untuk menilai kinerja karyawan. dengan mematuhi peraturan-peraturan kerja perusahaan, karyawan dapat bersaing dengan karyawan lainnya dan dapat termotivasi untuk jenjang karir yang lebih tinggi. Sehingga menghasilkan kinerja yang maksimal.

Penelitian dari (Sungkono, 2013) menyatakan pengembangan karir berpengaruh positif dan signifikan terhadap motivasi kerja Karyawan PT Excel Utama Indonesia Karawang. Penelitian yang dilakukan (Umar, 2015) yang menyatakan bahwa pengembangan karir berpengaruh positif dan siginfikan terhadap motivasi kerja. Dewi \& Utama (2016) menyatakan pengembangan karir berpengaruh positif dan signifikan terhadap motivasi kerja pada Karya Mas Art Gallery. (Lisdiani \& Ngatno (2017) menyatakan bahwa pengembangan karir berpengaruh signifikan terhadap motivasi kerja, artinya dengan adanya pengembangan karir yang baik maka karyawan akan merasa termotivasi sehingga menciptakan rasa puas dalam melaksanakan pekerjaan. Motivasi kerja memiliki pengaruh positif dan signifikan terhadap kinerja karyawan Elqadri et al. (2015). Motivasi kerja yang tinggi akan mampu membuat kinerja karyawan menjadi meningkat.

$\mathrm{H}_{1}$ : Pengembangan karir berpengaruh positif dan signifikan terhadap motivasi kerja karyawan

Penelitian yang dilakukan oleh Bianca et al. (2014) menemukan bahwa pengembangan karir karyawan secara langsung memberikan pengaruh positif terhadap kinerja karyawan, yang artinya kinerja karyawan secara tidak langsung juga mempengaruhi efektivitas perusahaan. Hasil penelitian yang dilakukan oleh 
Caroline \& Susan (2015) menunjukkan bahwa kemajuan karir berpengaruh secara positif dan signifikan terhadap kinerja karyawan di Kenyatta University. Penelitian dari Purwanis et al. (2014) dengan judul Pengaruh Pengembangan karir, Promosi Jabatan, Karakteristik Pekerjaan dan Motivasi Berpretasi Terhadap Kinerja Pegawai Dinas Kesehatan Kabupaten Kerinci. Penelitian tersebut menyatakan Pengembangan karir berpengaruh positif signifikan terhadap kinerja pegawai Dinas Kesehatan Kabupaten Kerinci. Dalam penelitian Umar (2015) berpendapat bahwa pengembangan karir berpengaruh positif siginifikan terhadap kinerja karyawan.

Hal ini didukung oleh pendapat Mukhlis (2016) yang menyatakan bahwa pengembangan karir berpengaruh positif dan signifikan terhadap kinerja karyawan.

$\mathrm{H}_{2}$ : Pengembangan Karir berpengaruh Positif Signifikan terhadap kinerja karyawan

Hasil penelitian yang dilakukan oleh Zameer et al. (2014) menunjukkan bahwa motivasi secara signifikan mempengaruhi kinerja karyawan di industri minuman Pakistan. Penelitian Charity (2015) juga mengemukakan bahwa pengembangan kair berpengaruh positif dan signifikan terhadap kinerja karyawan. Takahashi (2006) penelitian menunjukkan bahwa motivasi berpengaruh positif terhadap kinerja karyawan. Motivasi kerja memiliki pengaruh positif dan signifikan terhadap kinerja karyawan Elqadri et al. (2015). Motivasi kerja yang tinggi akan mampu membuat kinerja karyawan menjadi meningkat. penelitian yang dilakukan oleh Amalia \& Fakhri (2016) bahwa motivasi kerja mempengaruhi kinerja karyawan.

$\mathrm{H}_{3}$ : Motivasi Kerja berpengaruh Positif Signifikan Terhadap Kinerja Karyawan

Penelitian yang dilakukan oleh Umar (2015) mengenai pengaruh pengembangan karir terhadap kinerja karyawan melalui mediasi motivasi kerja mendapat hasil bahwa motivasi kerja dapat memediasi pengaruh pengembangan karir terhadap kinerja karyawan.penelitian yang dilakukan oleh Dewi \& Utama (2016) bahwa motivasi kerja dapat memediasi pengaruh pengembangan karir terhadap kinerja karyawan. semakin baik pengembangan karir karyawan dan semakin baik pula kinerja karyawan. Balbed \& Sintaasih (2019) membuktikan bahwa motivasi kerja mampu memediasi pengaruh pengembangan karir terhadap kinerja karyawan.

Penelitian yang dilakukan oleh Sari \& Sriathi (2019) menyatakan Motivasi kerja berpengaruh dan signifikan terhadap kinerja karyawan serta mampu memediasi pengaruh pengembangan karir terhadap kinerja karyawan.

$\mathrm{H}_{4}$ : Motivasi kerja mampu memediasi hubungan antara pengembangan karir terhadap kinerja karyawan.

\section{METODE PENELITIAN}

Lokasi penelitian ini di lakukan di BPR Lestari yang yang berlokasi di Jalan Raya Sesetan No 45 Denpasar. Lokasi ini dipilih karena terdapat masalah dengan pengembangan karir, motivasi kerja dan kinerja karyawan. Variabel ekogen dalam penelitian ini adalah pengembangan karir (X). Variabel endogen dalam penelitian ini adalah kinerja karyawan $(\mathrm{Y})$ sementara variabel mediasi dalam penelitian ini adalah (M). 
Kinerja merupakan hasil kerja yang dihasilkan baik dari segi kualitas maupun kuantitas pekerjaannya dan dapat dipertanggungjawabkan sesuai dengan prestasi kerja yang dihasilkan oleh karyawan sesuai dengan pekerjaan di dalam perusahaan, Kinerja karyawan dapat diukur dengan enam indikator Sari (2016) yakni Kualitas, merupakan kualitas pekerjaan yang dihasilkan, kesempurnaan tugas terhadap keterampilan dan kemampuan karyawan. Adapun persepsi responden yang akan dinilai tentang indikator kualitas adalah Saya akan berusaha untuk menyelesaikan pekerjaan dengan penuh rasa tanggung jawab yang maksima; kuantitas, merupakan jumlah yang dihasilkan dinyatakan dalam istilah seperti jumlah unit, jumlah siklus aktivitas yang diselesaikan. Adapun persepsi responden yang akan dinilai tentang indikator kualitas adalah saya bekerja sesuai dengan standar mutu yang ditetapkan oleh perusahaan; disiplin kerja, merupakan suatu sikap yang patuh dan taat pada peraturan-peraturan yang ada diperusahaan atau di tempat kerja. Adapun persepsi responden yang akan dinilai tentang indikator Disiplin kerja adalah Saya hadir dengan tepat waktu sesuai dengan jadwal yang sudah ditentukan di tempat kerja; efesiensi dalam melaksanakan tugas merupakan dalam menyelesaikan pekerjaannya sesuai dengan target waktu yang ditentukan. Adapun persepsi responden yang akan dinilai tentang indikator Efisiensi adalah Saya menyelesaikan pekerjaan yang diberikan sesuai dengan target waktu yang di tentukan; kepemimpinan, merupakan proses yang mempengaruhi atau memberi perintah kepada karyawan yang diberikan oleh peminpin. Adapun persepsi responden yang akan dinilai tentang indikator kepemimpinan adalah Saya mematuhi perintah dari atasan; kejujuran, merupakan mengakui, memberikan informasi sesuai dengan kenyataan dan kebenaran. Adapun persepsi responden yang akan dinilai tentang indikator kejujuran adalah saya jujur dalam bekerja.

Pengembangan karir adalah suatu rangkaian posisi atau jabatan yang ditempati seorang selama masa kehidupannya tertentu atau peningkatanpeningkatan pribadi yang dilakukan seseorang untuk mencapai suatu rencana karir. Pengembangan karir dapat diukur dengan indikator Flippo (2009) yakni 1) kesesuaian keahlian dalam pekerjaan, merupakan suatu proses yang diinginkan karyawan yang sesuai dengan keinginan karyawan. Adapun persepsi responden yang akan dinilai tentang indikator kesesuaian keahlian adalah karir saya sudah sesuai dengan keahlian yang saya milik. Kesempatan berkarir, merupakan yang sama bagi seluruh karyawan dalam suatu jabatan yang diterima atau didapatkan pleh karyawan. Adapun persepsi responden yang akan dinilai tentang indikator kesempatan berkarir adalah saya mendapatkan kesempatan karir sama dengan karyawan yang lain. 2) Peran Pendidikan dapat membantu meningkatkan kemampuan dalam melaksanakan pekerjaan yang merupakan proses Pendidikan jangka pendek yang dapat membantu karyawan untuk melaksanakan pekerjaan yang maksimal. Adapun persepsi responden yang akan dinilai tentang indikator pendidikan adalah Pendidikan yang diberikan akan membantu meningkatkan kemampuan. Penyebaran informasi mengenai kesempatan berkarir, merupakan penyebaran pesan yang sesuai dengan kenyataan mengenai karir di perusahan. Adapun persepsi responden yang akan dinilai tentang indikator penyebaran informasi adalah perusahaan menyebar informasi mengenai kesempatan karir. 3) Kejelasan informasi kesempatan karir yang diberikan perusahaan, merupakan 
penjelasan yang sesuai dengan kenyataan karir diperusahaan. Adapun persepsi responden yang akan dinilai tentang indikator kejelasan informasi adalah perusahaan memberikan informasi yang jelas kepada setiap karyawan. 4) Kejelasan rencana karir yang diberikan perusahaan, merupakan penjelasan pesan atau informasi yang diberikan perusahaan kepada setiap karyawan. Adapun persepsi responden yang akan dinilai tentang indikator kejelasan rencana karir adalah perusahaan memberikan rencana karir yang jelas kepada setiap karyawan.

Motivasi kerja adalah Motivasi kerja merupakan upaya dorongan yang timbul dari diri sendiri untuk melakukan pekerjaan yang sesuai dengan semua keahlian yang dimiliki agar tujuan dari perusahaan dapat tercapai. Motivasi kerja karyawan dapat diukur berdasarkan indikator-indikator Ardana et al. (2012) yakni 1) Penempatan kerja yang tepat merupakan penugasan yang diberikan atasan yang menempatkan karyawan pada posisi yang sesuai dengan kemampuannya. Adapun persepsi responden yang akan dinilai tentang indikator penempatakan kerja yang tepat adalahperusahaan menempatkan saya pada posisi yang tepat. 2) Kondisi pekerjaan yang nyaman merupakan kondisi dimana karyawan merasakan ada kenyamanan di dalam melakukan setiap pekerjaannya. Adapun persepsi responden yang akan dinilai tentang indikator kondisi pekerjaan yang nyaman adalah saya merasa nyaman pada saat melaksanakan pekerjaan. 3) Fasilitas rekreasi merupakan sarana yang diberikan oleh perusahaan untuk karyawan melakukan kegiatan seperti memberi liburan ke tempat wisata. Adapun persepsi responden yang akan dinilai tentang indikator fasilitas rekreasi adalah perusahaan memberikan saya fasiltas rekreasi. 4) Jaminan Kesehatan adalah salah satu fasiliatas yang diberikan perusahaan berupa perilindungan kesehatan agar karyawan memperoleh jaminan kesehatan dan perlindungan dalam memenuhi kebutuhan dasar kesehatannya. Adapun persepsi responden yang akan dinilai tentang indikator jaminan kesehatan adalah saya mendapatkan jaminan kesehatan yang layak dari perusahaan.

Teknik analisis data dalam penelitian ini digolongkan menjadi 2 yaitu: analisis statistik deskriptif dan analisis statistik inferensial. Analisis statistik deskriptif digunakan untuk mendeskripsikan variabel penelitian dan karakteristik responden. Analisis statistik inferensial digunakan untuk menguji hipotesis. Analisis jalur digunakan untuk menentukan hubungan 3 variabel atau lebih dalam mengkonfirmasi dan menolak hipotesis. Analisis jalur digunakan untuk menganalisis pola hubungan antar variabel dengan tujuan untuk mengetahui pengaruh langsung maupun tidak langsung variabel eksogen terhadap variabel endogen. Dasar perhitungan koefisian jalur adalah analisis korelasi dan regresi dan dalam perhitungannya menggunakan software dengan program SPSS for windows. Diagram jalur dibuat atas dasar tujuan untuk membantu menganalisis dan menginterpretasikan hubungan antar variabel yang dihipotesiskan.

Metode penentuan sampel yang digunakan adalah sampel jenuh, dimana Populasi dalam penelitian ini adalah seluruh karyawan di BPR Lestari Cabang Sesetan Denpasar. Sampel yang digunakan dalam penelitian ini adalah 74 karyawan. 
Tabel 2.

Jabatan dan Jumlah Karyawan BPR Lestari Cabang Sesetan

\begin{tabular}{llc}
\hline No & \multicolumn{1}{c}{ Jabatan } & $\begin{array}{c}\text { Jumlah } \\
\text { (orang) }\end{array}$ \\
\hline 1 & Electronic Channel Operation & 6 \\
2 & IT Sofware \& Development & 6 \\
3 & Customer service & 4 \\
4 & teller & 4 \\
5 & Staf Back Office & 12 \\
6 & Marketing Funding & 10 \\
7 & Marketing Landing & 10 \\
8 & Generasi Lestari & 10 \\
9 & Lestari First Manager & 10 \\
10 & Security & 4 \\
& & \\
& Jumlah & 74 \\
\hline
\end{tabular}

Sumber: Data diolah, 2019

\section{HASIL DAN PEMBAHASAN}

Karekteristik responden dikelompokkan berdasarkan beberapa kriteria yang disajikan dalam Tabel 3.

Tabel 3.

Karakteristik Responden Menurut Usia

\begin{tabular}{cccc}
\hline No & Umur (Tahun) & Jumlah (Orang) & Jumlah (Persentase \\
\hline 1 & 21 - 25 Tahun & 16 & 21,6 \\
2 & 26 - 30 Tahun & 34 & 45,9 \\
3 & 31 - 35 Tahun & 14 & 18,9 \\
4 & 35 Tahun & 10 & 13,5 \\
& Jumlah & 74 & 100 \\
\hline
\end{tabular}

Sumber: Data primer diolah, 2019

Pada Tabel 3. dapat dilihat responden dengan usia dari 26 - 30 tahun dengan presentase sebesar 45,9 persen, sedangkan untuk kelompok usia terendah $>35$ tahun dengan persentase 13,5 persen. Hal ini menunjukan bahwa karyawan BPR Lestari Cabang Sesetan Denpasar didominasi oleh usia 26-30 tahun.

Tabel 4.

Karakteristik Responden Menurut Jenis Kelamin

\begin{tabular}{cccc}
\hline No & Jenis Kelamin & Jumlah (Orang) & $\begin{array}{c}\text { Jumlah (Persentase } \\
\text { \%) }\end{array}$ \\
\hline 1 & Laki - Laki & 29 & 39,2 \\
2 & Perempuan & 45 & 60,8 \\
& Jumlah & 74 & 100 \\
\hline
\end{tabular}

Sumber: Data diolah, 2019

Tabel 4. dapat dilihat responden dengan jenis kelamin perempuan sebanyak 45 orang dengan presentase 60,8 persen, sedangkan sisanya laki-laki sebanyak 29 orang dengan presentase 39,2 persen. Artinya sebagian besar karyawan BPR Lestari 
Cabang Sesetan mempekerjakan tenaga perempuan disebabkan oleh beban kerja yang ada di BPR Lestari Cabang Sesetan Denpasar lebih mendominasi dengan tenaga kerja perempuan karena perempuan lebih menarik untuk bertatapan langsung dengan nasabah.

Tabel 5.

Karakteristik Responden Menurut Pendidikan Terakhir

\begin{tabular}{cccc}
\hline No & Pendidikan Terakhir & $\begin{array}{c}\text { Jumlah } \\
\text { (Orang) }\end{array}$ & $\begin{array}{c}\text { Jumlah } \\
\text { (Persentase \%) }\end{array}$ \\
\hline 1 & SMA & 13 & 17,6 \\
2 & Diploma & 20 & 27,0 \\
3 & S1 & 36 & 48,6 \\
4 & S2 & 5 & 6,8 \\
& Jumlah & $\mathbf{7 4}$ & $\mathbf{1 0 0}$ \\
\hline
\end{tabular}

Sumber: Data diolah, 2019

Pada Tabel 5. dapat dilihat besar responden dengan pendidikan terakhir S1 sebanyak 36 orang dengan presentase 48,6 persen, sedangkan sisanya Diploma sebanyak 20 orang dengan presentase 27,0 persen. Sedangkan kelompok pendidikan SMA yang dimiliki responden sebanyak 13 orang dengan presentase 17,6 persen dan kelompok pendidikan S2 yang dimiliki responden merupakan paling kecil sebanyak 5 orang dengan presentase 6,8 persen. Hal ini menunjukan bahwa BPR Lestari Cabang Sesetan Denpasar didominasi oleh pendidikan S1 Dengan presentase 48,6 persen. Hal ini menyatakan bahwa pendidikan S1 miliki skill dan keahlian dibidangnya, khususnya dibidang perbankan.

Tabel 6.

Karakteristik Responden Menurut Masa Kerja

\begin{tabular}{cccc}
\hline No & Masa Kerja & Jumlah (Orang) & Jumlah (Persentase \\
\hline 1 & 1 - 5 Tahun & 30 & 40,5 \\
2 & 6 - 10 Tahun & 31 & 41,9 \\
3 & $>$ 10 Tahun & 13 & 17,6 \\
& Jumlah & 74 & 100 \\
\hline
\end{tabular}

Sumber: Data diolah, 2019

Pada Tabel 6. menunjukan sebagaian besar responden memiliki masa kerja 6-10 tahun yang berjumlah 31 orang dengan presentase 41,9 persen, sedangkan sisanya responden yang memiliki masa kerja lebih dari 1-5 tahun yang berjumlah 30 orang dengan presentase 40,5 persen dan yang terendah memiliki masa kerja lebih dari 15-20 tahun yang berjumlah 13 orang dengan presentase 17,6 persen.

Pengujian validitas bertujuan untuk memeriksa apakah kusioner sebagai instrument penelitian sudah tepat dalam mengukur inidkator penelitian. Ketentuan instrument dapat dikatakan valid apabila korelasi tiap faktor sama dengan 0,30 atau lebih maka faktor tersebut merupakan construct yang kuat.

Hasil uji validitas pada Tabel 7. menunjukkan bahwa seluruh instrumen penelitian yang digunakan untuk mengukur variabel Pengembangan Karir, Motivasi Kerja dan Kinerja Karyawan memiliki nilai koefisien korelasi dengan skor total seluruh item pernyataan lebih besar dari 0,3 . Hal ini menunjukkan bahwa 
butir-butir pernyataan dalam instrument penelitian tersebut valid dan layak digunakan sebagai instrument penelitian.

Tabel 7.

Rekapitulasi Hasil Uji Validitas Instrumen Penelitian

\begin{tabular}{|c|c|c|c|c|}
\hline Variabel & Indikator & $\begin{array}{c}\text { Koefisien } \\
\text { Korelasi }\end{array}$ & $\begin{array}{c}\text { Koefisien } \\
\text { Batas }\end{array}$ & Keterangan \\
\hline \multirow{6}{*}{ Pengembangan Karir (X) } & $\mathrm{X}_{.1}$ & 0,729 & 0,3 & Valid \\
\hline & $\mathrm{X}_{.2}$ & 0,807 & 0,3 & Valid \\
\hline & $\mathrm{X}_{.3}$ & 0,793 & 0,3 & Valid \\
\hline & $\mathrm{X}_{4}$ & 0,705 & 0,3 & Valid \\
\hline & $\mathrm{X}_{.5}$ & 0,672 & 0,3 & Valid \\
\hline & $\mathrm{X}_{.6}$ & 0,761 & 0,3 & Valid \\
\hline \multirow{4}{*}{ Motivasi Kerja (M) } & $\mathrm{M}_{.1}$ & 0,927 & 0,3 & Valid \\
\hline & $\mathrm{M}_{2}$ & 0,878 & 0,3 & Valid \\
\hline & M.3 & 0,813 & 0,3 & Valid \\
\hline & M.4 & 0,841 & 0,3 & Valid \\
\hline \multirow{6}{*}{ Kinerja Karyawan (Y) } & $\mathrm{Y}_{\cdot 1}$ & 0,910 & 0,3 & Valid \\
\hline & $\mathrm{Y}_{.2}$ & 0,832 & 0,3 & Valid \\
\hline & $\mathrm{Y}_{.3}$ & 0,834 & 0,3 & Valid \\
\hline & Y.4 & 0,863 & 0,3 & Valid \\
\hline & Y.5 & 0,910 & 0,3 & Valid \\
\hline & $\mathrm{Y}_{.6}$ & 0,925 & 0,3 & Valid \\
\hline
\end{tabular}

Sumber: Data diolah, 2019

Tabel 8.

Rekapitulasi Hasil Uji Reliabilitas Instrumen Penelitian

\begin{tabular}{clcc}
\hline No. & \multicolumn{1}{c}{ Variabel } & $\begin{array}{c}\text { Cronbach's } \\
\text { Alpha }\end{array}$ & Keterangan \\
\hline 1 & Pengembangan Karir (X) & 0,823 & Reliabel \\
3 & Motivasi Kerja (M) & 0,885 & Reliabel \\
4 & Kinerja Karyawan (Y) & 0,939 & Reliabel \\
\hline
\end{tabular}

Sumber: Data diolah, 2019

Reliabilitas bertujuan untuk mengetahui konistensi alat ukur yang dapat digunakan,sehingga bila alat ukur digunakan kembali maka akan mendaptkan hasil yang sama. Pengujian statistik dengan menggunakan Cronbach's alpha instrument dikatakan reliable bila variabel memiliki nilai alpha lebih dari 0,60.

Hasil uji reliabilitas yang disajikan dalam Tabel 8. menunjukkan bahwa seluruh instrumen penelitian memiliki koefisien Cronbach's Alpha lebih dari 0,60. Jadi dapat dinyatakan bahwa seluruh variabel telah memenuhi syarat reliabilitas atau kehandalan sehingga dapat digunakan untuk melakukan penelitian.

Tabel 9. menunjukkan Pengembangan Karir secara keseluruhan baik hal ini dapat dilihat dari keseluruhan rata-rata nilai Pengembangan Karir yaitu 3,64. Hasil penyebaran kusioner menunjukan bahwa kinerja karyawan perusahaan baik. Nilai rata-rata tertinggi pada pernyataan "Karir saya sudah sesuai dengan keahlian yang saya milik". Dengan nilai rata-rata 3,85. Hal ini menunjukan bahwa karyawan sudah bekerja sesuai dengan keahlian yang dimiliki masing-masing. 
Tabel 9.

Deskripsi Jawaban Responden Terhadap Pengembangan Karir

\begin{tabular}{|c|c|c|c|c|c|c|c|c|}
\hline \multirow{2}{*}{ No } & \multirow{2}{*}{ Pernyataan } & \multicolumn{5}{|c|}{ Frekuensi Jawaban Responden } & \multirow{2}{*}{ Rata-Rata } & \multirow{2}{*}{ Kriteria } \\
\hline & & STS & TS & $\mathbf{N}$ & $\mathbf{S}$ & SS & & \\
\hline 1 & $\begin{array}{l}\text { Perusahaan memberikan } \\
\text { informasi yang jelas } \\
\text { kepada setiap karyawan }\end{array}$ & 0 & 8 & 16 & 29 & 21 & 3,85 & Baik \\
\hline 2 & $\begin{array}{l}\text { Perusahaan memberikan } \\
\text { informasi yang jelas } \\
\text { kepada setiap karyawan }\end{array}$ & 1 & 18 & 9 & 31 & 15 & 3,55 & Baik \\
\hline 3 & $\begin{array}{l}\text { Perusahaan memberikan } \\
\text { informasi yang jelas } \\
\text { kepada setiap karyawan }\end{array}$ & 3 & 11 & 10 & 41 & 9 & 3,57 & Baik \\
\hline 4 & $\begin{array}{l}\text { Perusahaan memberikan } \\
\text { informasi yang jelas } \\
\text { kepada setiap karyawan }\end{array}$ & 5 & 11 & 7 & 38 & 13 & 3,58 & Baik \\
\hline 5 & $\begin{array}{l}\text { Perusahaan memberikan } \\
\text { informasi yang jelas } \\
\text { kepada setiap karyawan }\end{array}$ & 3 & 12 & 21 & 23 & 15 & 3,47 & Baik \\
\hline 6 & $\begin{array}{l}\text { Perusahaan memberikan } \\
\text { informasi yang jelas } \\
\text { kepada setiap karyawan }\end{array}$ & 1 & 5 & 17 & 36 & 15 & 3,80 & Baik \\
\hline & Rata-rata keseluruhan va & abel P & gemb & 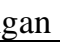 & & & 3,64 & Baik \\
\hline
\end{tabular}

Nilai rata-rata terendah terdapat pada pernyataan "Perusahaan memberikan informasi yang jelas kepada setiap karyawan". dengan nilai rata-rata sebesar 3,47. Hal ini menunjukan bahwa perusahaan masih kurang dalam memberikan memberikan informasi kepada karyawan untuk meningkatkan karirnya dalam perusahaan. Secara keseluruhan rata-rata jawaban responden terhadap variabel Motivasi Kerja memiliki nilai sebesar 3,44.

Tabel 10.

Deskripsi Jawaban Responden Terhadap Variabel Motivasi Kerja

\begin{tabular}{|c|c|c|c|c|c|c|c|c|}
\hline \multirow{2}{*}{ No } & \multirow{2}{*}{ Pernyataan } & \multicolumn{5}{|c|}{ Frekuensi Jawaban Responden } & \multirow{2}{*}{ Rata-Rata } & \multirow{2}{*}{ Kriteria } \\
\hline & & STS & TS & $\mathbf{N}$ & $\mathbf{S}$ & SS & & \\
\hline 1 & $\begin{array}{l}\text { Perusahaan menempatkan } \\
\text { saya pada posisi yang tepat }\end{array}$ & 1 & 3 & 23 & 36 & 11 & 3,72 & Baik \\
\hline 2 & $\begin{array}{l}\text { Saya merasa nyaman pada } \\
\text { saat melaksanakan } \\
\text { Pekerjaan. }\end{array}$ & 1 & 12 & 15 & 33 & 13 & 3,61 & Baik \\
\hline 3 & $\begin{array}{l}\text { Perusahaan memberikan } \\
\text { saya fasiltas rekreasi }\end{array}$ & 1 & 17 & 22 & 26 & 8 & 3,31 & Cukup \\
\hline 4 & $\begin{array}{l}\text { Saya mendapatkan jaminan } \\
\text { kesehatan yang layak dari } \\
\text { perusahaan. }\end{array}$ & 4 & 19 & 20 & 27 & 4 & 3,11 & Cukup \\
\hline & Rata-rata keseluruhan & ariabel & otiva & Ker & & & 3,44 & Baik \\
\hline
\end{tabular}

Sumber: Data diolah, 2019

Hasil penyebaran kuesioner menunjukkan bahwa pernyataan "Perusahaan menempatkan saya pada posisi yang tepat", dengan nilai rata-rata 3,72. Hal ini 
berarti karyawan merasa nyaman dengan pekerjaan yang diberikan dan sesuai dengan kemampuan. Nilai rata-rata terendah terdapat pada pernyataan "Saya mendapatkan jaminan kesehatan yang layak dari perusahaan", dengan nilai ratarata sebesar 3,11. Hal ini menunjukan bahwa jaminan kesehatan pada tempat penelitian menurut responden kurang layak, seharusnya jaminan kesehatan karyawan diberikan secara layak.

\section{Tabel 11.}

Deskripsi Jawaban Responden Terhadap Variabel Kinerja Karyawan

\begin{tabular}{|c|c|c|c|c|c|c|c|c|}
\hline \multirow{2}{*}{ No } & \multirow{2}{*}{ Pernyataan } & \multicolumn{5}{|c|}{ FrekuensiJawaban Responden } & \multirow{2}{*}{ Rata-Rata } & \multirow{2}{*}{ Kriteria } \\
\hline & & STS & TS & $\mathbf{N}$ & $\mathbf{S}$ & SS & & \\
\hline 1 & $\begin{array}{l}\text { Saya akan berusaha untuk } \\
\text { menyelesaikan pekerjaan } \\
\text { dengan penuh rasa tanggung } \\
\text { jawab yang maksimal }\end{array}$ & 2 & 21 & 11 & 26 & 14 & 3,39 & Cukup \\
\hline 2 & $\begin{array}{l}\text { Saya bekerja sesuai dengan } \\
\text { standar mutu yang ditetapkan } \\
\text { oleh perusahaan }\end{array}$ & 0 & 13 & 11 & 37 & 13 & 3,68 & Baik \\
\hline 3 & $\begin{array}{l}\text { Saya hadir dengan tepat waktu } \\
\text { sesuai dengan jadwal yang } \\
\text { sudah ditentukan di tempat } \\
\text { kerja }\end{array}$ & 0 & 16 & 12 & 35 & 11 & 3,55 & Baik \\
\hline 4 & $\begin{array}{l}\text { Saya menyeyelesaikan } \\
\text { pekerjaan yang di berikan } \\
\text { sesuai dengan target waktu } \\
\text { yang di tentukan }\end{array}$ & 7 & 12 & 22 & 23 & 10 & 3,23 & Cukup \\
\hline 5 & $\begin{array}{l}\text { Saya mematuhi perintah dari } \\
\text { atasan }\end{array}$ & 9 & 16 & 16 & 23 & 10 & 3,12 & Cukup \\
\hline 6 & $\begin{array}{l}\text { Saya jujur dalam bekerja } \\
\text { Rata-rata keseluruhan var }\end{array}$ & $\begin{array}{c}0 \\
\text { bel Kir }\end{array}$ & $\begin{array}{l}15 \\
\text { ja K }\end{array}$ & $\begin{array}{l}30 \\
\text { yaw }\end{array}$ & 22 & 7 & $\begin{array}{l}3,28 \\
3,38\end{array}$ & $\begin{array}{l}\text { Cukup } \\
\text { Cukup }\end{array}$ \\
\hline
\end{tabular}

Sumber: Data diolah, 2019

Secara keseluruhan rata-rata jawaban responden terhadap variabel Kinerja Karyawan memiliki nilai sebesar 3,38. Hasil penyebaran kuisioner menunjukkan bahwa Kinerja Karyawan perusahaan baik. Nilai rata-rata tertinggi terdapat pada pernyataan "Saya bekerja sesuai dengan standar mutu yang ditetapkan oleh perusahaan", dengan nilai rata-rata 3,68. Hal ini menunjukan karyawan sudah bekerja sesuai dengan kriteria yang ditetapkan oleh perusahaan. Nilai rata-rata terendah terdapat pada pernyataan "Saya mematuhi perintah dari atasan", dengan rata-rata sebesar 3,12. Hal ini menunjukan bahwa karyawan kurang mematuhi aturan dari atasan. Uji normalitas data penelitian ditujukan untuk menentukan distribusi persebaran data. Hasil uji normalitas disajikan pada Tabel 12.

Tabel 12.

Hasil Uji Normalitas Struktur 1

\begin{tabular}{lc}
\hline & Unstandardized Residual \\
\hline $\mathrm{N}$ & 74 \\
Test Statistics & 0,094 \\
Asymp. Sig. (2-tailed) & 0,169 \\
\hline Sumber: Data diolah, 2019
\end{tabular}


Berdasarkan Tabel 12. dapat dilihat bahwa nilai Asymp. Sig. (2-tailed) sebesar 0,169, hasil tersebut mengindikasikan bahwa model persamaan regresi tersebut berdistribusi normal karena nilai Asymp. Sig. (2-tailed) sebesar 0,200 dimana lebih besar dari nilai alpha 0,05 .

Tabel 13.

Hasil Uji Normalitas Struktur 2

\begin{tabular}{lc}
\hline & Unstandardized Residual \\
\hline $\mathrm{N}$ & 74 \\
Test Statistics & 0,059 \\
Asymp. Sig. (2-tailed) & 0,200 \\
\hline
\end{tabular}

Sumber: Data diolah, 2019

Berdasarkan Tabel 13. dapat dilihat bahwa nilai Asymp. Sig. (2-tailed) sebesar 0,200, sedangkan nilai dari Asymp.Sig (2-tailed) sebesar 0,200. hasil tersebut mengindikasikan bahwa model persamaan regresi tersebut berdistribusi normal karena nilai Asymp. Sig. (2-tailed) sebesar lebih besar dari nilai alpha 0,05.

Tabel 14.

Hasil Uji Multikoleniaritas

\begin{tabular}{llcc}
\hline \multicolumn{1}{c}{ Persamaan Struktur } & \multicolumn{1}{c}{ Variabel } & Tolerance & VIF \\
\hline $\mathrm{M}=\beta_{1} \mathrm{X}+\mathrm{e}_{1}$ & Pengembangan Karir (X) & 1,000 & 1,000 \\
$\mathrm{Y}=\beta_{1} \mathrm{X}+\beta_{2} \mathrm{M}+\mathrm{e}_{2}$ & Pengembangan Karir (X) & 0,498 & 2,007 \\
& Motivasi Kerja $(\mathrm{M})$ & 0,498 & 2,007 \\
\hline
\end{tabular}

Sumber: Data diolah, 2019

Berdasarkan Tabel 14. dapat dilihat bahwa nilai tolerance dan VIF dari variabel Pengembangan Karir dan Motivasi Kerja menunjukkan nilai tolerance untuk setiap variabel lebih besar dari 0,1 dan nilai VIF lebih kecil dari 10 yang berarti model persamaan regresi bebas dari multikolinearitas.

\section{Tabel 15.}

Hasil Uji Heteroskedastisitas Struktur 1

\begin{tabular}{llccccc}
\hline Model & \multicolumn{2}{c}{$\begin{array}{c}\text { Unstandardized } \\
\text { Coefficients }\end{array}$} & $\begin{array}{c}\text { Standardized } \\
\text { Coefficients }\end{array}$ & & t & Sig. \\
\cline { 2 - 5 } & B & Std. Error & Beta & & \\
\hline 1 & $\begin{array}{l}\text { (Constant) } \\
\text { Pengembangan }\end{array}$ & 2.322 & .842 & & 2.759 & .007 \\
& $\begin{array}{l}\text { Karir } \\
\text { a. Dependent Variable: ABS_RES1 }\end{array}$ & -.022 & .038 & -.068 & -.577 & .566 \\
\hline
\end{tabular}

Sumber: Data diolah, 2019

Pada Tabel 15. dapat dilihat bahwa nilai signifikansi dari variabel Pengembangan Karir sebesar 0,566. Nilai tersebut lebih besar dari 0,05 yang berarti tidak terdapat pengaruh antara variabel bebas terhadap absolute residual. Dengan demikian, model yang dibuat tidak mengandung gejala heteroskedastisitas, karena nilai hasil uji heteroskedastisitas sebesar 0,566 yang berarti kurang dari 0,05 dan 
dapat dikatakan tidak signifikan. Hasil uji heteroskedastisitas struktur 2 dari dapat dilihat pada Tabel 14 .

Tabel 16.

Hasil Uji Heteroskedastisitas Struktur 2

\begin{tabular}{|c|c|c|c|c|c|}
\hline \multirow[t]{2}{*}{ Model } & \multicolumn{2}{|c|}{$\begin{array}{c}\text { Unstandardized } \\
\text { Coefficients }\end{array}$} & \multirow{2}{*}{$\begin{array}{c}\begin{array}{c}\text { Standardized } \\
\text { Coefficients }\end{array} \\
\text { Beta }\end{array}$} & \multirow[t]{2}{*}{$\mathbf{t}$} & \multirow[t]{2}{*}{ Sig. } \\
\hline & B & $\begin{array}{c}\text { Std. } \\
\text { Error }\end{array}$ & & & \\
\hline \multirow{4}{*}{$\begin{array}{ll}1 & \text { (Constant) } \\
& \text { Pengembangan Karir } \\
& \text { Motivasi Kerja } \\
& \text { Dependent Variable: AB }\end{array}$} & 3.071 & 1.005 & & 3.057 & .003 \\
\hline & .067 & .062 & .179 & 1.084 & .282 \\
\hline & -.144 & .087 & -.273 & -1.654 & .103 \\
\hline & $\mathrm{ES} 2$ & & & & \\
\hline
\end{tabular}

Sumber: Data diolah, 2019

Pada Tabel 16. dapat dilihat bahwa nilai signifikansi dari variabel Pengembangan Karir dan Motivasi Kerja, masing-masing sebesar 0,282 dan 0,103. Nilai tersebut lebih besar dari 0,05 yang berarti tidak terdapat pengaruh antara variabel bebas terhadap absolute residual. Dengan demikian, model yang dibuat tidak mengandung gejala heteroskedastisitas, karena nilai hasil uji heteroskedastisitas variabel pengembangan karir dan motivasi kerja sebesar 0,282 dan 0,103 yang berarti kurang dari 0,05 dan dapat dikatakan tidak signifikan.

Nilai koefisien regresi variabel orientasi pasar bernilai positif dengan nilai signifikansi uji t kurang dari 0,05. Hal ini menunjukkan bahwa variabel Pengembangan Karir memiliki pengaruh positif yang signifikan terhadap variabel Motivasi Kerja. Besarnya pengaruh variabel bebas terhadap variabel terikat yang ditunjukkan oleh nilai determinasi total (R Square) sebesar 0,502 mempunyai arti bahwa sebesar 50,2\% variasi Motivasi Kerja dipengaruhi oleh variasi Pengembangan Karir sedangkan sisanya sebesar 49,8\% dijelaskan oleh faktor lain yang tidak dimasukkan ke dalam model. Diperoleh hasil yang ditunjukan pada Tabel 15.

Tabel 17.

Hasil Analisis Jalur 1

\begin{tabular}{|c|c|c|c|c|c|}
\hline \multirow[t]{2}{*}{ Model } & \multicolumn{2}{|c|}{$\begin{array}{c}\text { Unstandardized } \\
\text { Coefficients }\end{array}$} & \multirow{2}{*}{$\begin{array}{c}\text { Standardized } \\
\text { Coefficients } \\
\text { Beta } \\
\end{array}$} & \multirow[t]{2}{*}{$\mathbf{t}$} & \multirow[t]{2}{*}{ Sig. } \\
\hline & B & Std. Error & & & \\
\hline (Constant) & 2.815 & 1.315 & & 2.141 & .036 \\
\hline $\begin{array}{l}\text { Pengembangan } \\
\text { Karir }\end{array}$ & .501 & .059 & .708 & 8.513 & .000 \\
\hline R Square & 0,502 & & & & \\
\hline F Statistik & 72,477 & & & & \\
\hline Sig. Uji F & 0,000 & & & & \\
\hline
\end{tabular}

Nilai koefisien regresi masing-masing variabel bebas bernilai positif dengan nilai signifikansi uji t kurang dari 0,05. Hal ini menunjukkan bahwa semua variabel bebas memiliki pengaruh positif yang signifikan terhadap variabel terikat. Besarnya pengaruh variabel bebas terhadap variabel terikat yang ditunjukkan oleh nilai 
determinasi total (R Square) sebesar 0,663 mempunyai arti bahwa sebesar 66,3\% variasi Kinerja Karyawan dipengaruhi oleh variasi Pengembangan Karir dan Motivasi Kerja, sedangkan sisanya sebesar 33,7\% dijelaskan oleh faktor lain yang tidak dimasukkan ke dalam model.

Tabel 18.

Hasil Analisis Jalur 2

\begin{tabular}{|c|c|c|c|c|c|}
\hline \multirow{2}{*}{ Variabel } & \multicolumn{2}{|c|}{$\begin{array}{c}\text { Unstandardized } \\
\text { Coefficients } \\
\end{array}$} & \multirow{2}{*}{$\begin{array}{l}\text { Standardized } \\
\text { Coefficients } \\
\text { Beta }\end{array}$} & \multirow{2}{*}{ t hitung } & \multirow{2}{*}{$\underset{t}{\text { Sig. uji }}$} \\
\hline & B & Std. Error & & & \\
\hline (Constant) & 5.423 & .969 & & 5.595 & .000 \\
\hline Pengembangan Karir (X) & .229 & .073 & .187 & 3.123 & .002 \\
\hline Motivasi Kerja (M) & .288 & .022 & .775 & 12.919 & .000 \\
\hline $\begin{array}{l}\text { R Square } \\
\text { F Statistik } \\
\text { Signifikansi Uji F }\end{array}$ & $\begin{array}{c}0,663 \\
69,693 \\
0,000\end{array}$ & & & & \\
\hline
\end{tabular}

Sumber: Data diolah, 2019

Nilai determinasi total sebesar 0,833 mempunyai arti bahwa sebesar 83,3\% variasi Kinerja Karyawan dipengaruhi oleh variasi Pengembangan Karir dan Motivasi Kerja, sedangkan sisanya sebesar 16,7\% djelaskan oleh faktor lain yang tidak dimasukkan ke dalam model. Hasil koefisien jalur pada hipotesis penelitian dapat digambarkan pada Gambar 1.

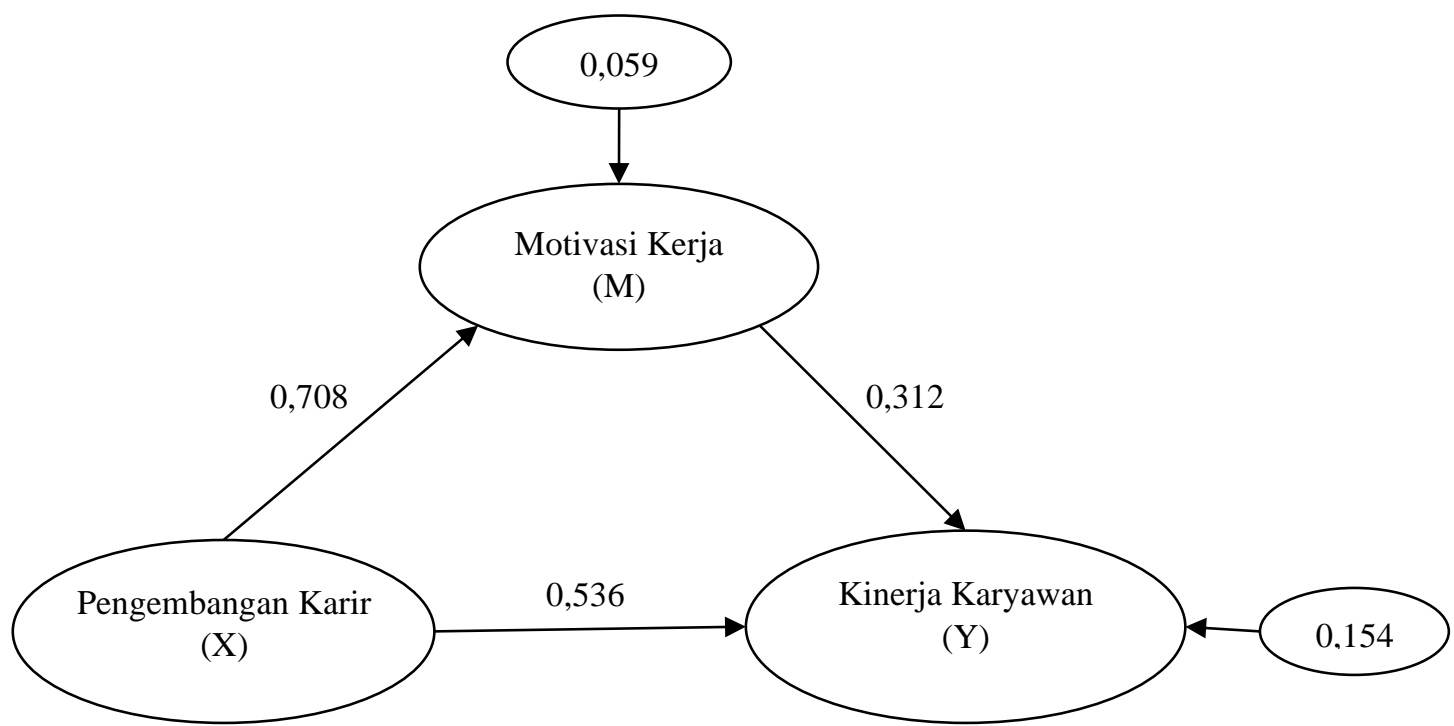

Gambar 1. Validasi Model Diagram Jalur Akhir

Sumber: Data diolah, 2019

Berdasarkan diagram jalur pada Gambar 1. maka dapat dihitung besarnya pengaruh langsung dan pengaruh tidak langsung serta pengaruh total antar variabel. Perhitungan pengaruh antar variabel dirangkum dalam Tabel 19. sebagai berikut. 
Tabel 19.

Pengaruh Langsung dan Pengaruh Tidak Langsung serta Pengaruh Total Pengembangan Karir (X), Motivasi Kerja (M), dan Kinerja Karyawan (Y)

\begin{tabular}{cccc}
\hline $\begin{array}{c}\text { Pengaruh } \\
\text { Variabel }\end{array}$ & $\begin{array}{c}\text { Pengaruh } \\
\text { Langsung }\end{array}$ & $\begin{array}{c}\text { Pengaruh Tidak Langsung Melalui } \\
\text { Perceived Value } \\
(\text { Y1 })(\boldsymbol{\beta} 1 \mathbf{x} \boldsymbol{\beta 3})\end{array}$ & Pengaruh Total \\
\hline $\mathrm{X} \rightarrow \mathrm{M}$ & 0,708 & - & 0,708 \\
$\mathrm{X} \rightarrow \mathrm{Y}$ & 0,563 & 0,221 & 0,773 \\
$\mathrm{M} \rightarrow \mathrm{Y}$ & 0,312 & - & 0,312 \\
\hline \multicolumn{2}{l}{ Sumber: Data diolah, 2019} & &
\end{tabular}

Tabel 19. menunjukkan bahwa pengaruh langsung Pengembangan Karir terhadap Motivasi Kerja adalah sebesar 0,708. Pengaruh langsung variabel Pengembangan Karir terhadap Kinerja Karyawan sebesar 0,563. Pengaruh langsung variabel Motivasi Kerja terhadap Kinerja Karyawan sebesar 0,312. Hal ini berarti bahwa variabel Kinerja Karyawan lebih besar dipengaruhi oleh Pengembangan Karir dari Motivasi Kerja. Sedangkan pengaruh tidak langsung variabel Pengembangan Karir terhadap Kinerja Karyawan melalui Motivasi Kerja sebesar 0,221. Jadi pengaruh total variabel Pengembangan Karir terhadap Kinerja Karyawan melalui Motivasi Kerja adalah sebesar 0,773 Jadi dapat disimpulkan bahwa lebih besar total pengaruh Pengembangan Karir terhadap Kinerja Karyawan yang melalui Motivasi Kerja, daripada pengaruh langsung Pengembangan Karir terhadap Kinerja Karyawan tanpa melalui variable Motivasi Kerja.

Berdasarkan hasil analisis pengaruh Pengembangan Karir terhadap Motivasi Kerja diperoleh nilai Signifikansi sebesar 0,000 dengan nilai koefisien beta 0,708 bernilai positif. Nilai Signifikansi $0,000<0,05$ mengindikasikan bahwa $\mathrm{H}_{0}$ ditolak dan $\mathrm{H}_{1}$ diterima. Hasil ini mempunyai arti bahwa Pengembangan Karir berpengaruh positif terhadap Motivasi Kerja. Semakin tinggi tingkat Pengembangan Karir maka tingkat Kinerja Karyawan juga akan semakin meningkat, begitu sebaliknya.

Penelitian dari Sungkono (2013) menyatakan pengembangan karir berpengaruh positif dan signifikan terhadap motivasi kerja Karyawan PT Excel Utama Indonesia Karawang. Penelitian yang dilakukan Umar (2015) yang menyatakan bahwa pengembangan karir berpengaruh positif dan siginfikan terhadap motivasi kerja.

Dewi \& Utama (2016) menyatakan pengembangan karir berpengaruh positif dan signifikan terhadap motivasi kerja pada Karya Mas Art Gallery. Lisdiani \& Ngatno (2017) menyatakan bahwa pengembangan karir berpengaruh signifikan terhadap motivasi kerja, artinya dengan adanya pengembangan karir yang baik maka karyawan akan merasa termotivasi sehingga menciptakan rasa puas dalam melaksanakan pekerjaan. Motivasi kerja memiliki pengaruh positif dan signifikan terhadap kinerja karyawan (Elqadri et al., 2015). Motivasi kerja yang tinggi akan mampu membuat kinerja karyawan menjadi meningkat.

Berdasarkan hasil analisis pengaruh Pengembangan Karir terhadap Kinerja Karyawan diperoleh nilai Signifikansi sebesar 0,002 dengan nilai koefisien beta 0,312 bernilai positif. Nilai Signifikansi $0,002<0,05$ mengindikasikan bahwa $\mathrm{H}_{0}$ ditolak dan $\mathrm{H}_{2}$ diterima. Hasil ini mempunyai arti bahwa Pengembangan Karir berpengaruh positif terhadap Kinerja Karyawan. Hal ini menandakan semakin 
tinggi nilai Pengembangan Karir maka Kinerja Karyawan akan meningkat, begitu juga sebaliknya.

Penelitian yang dilakukan oleh Bianca et al., (2014) menemukan bahwa pengembangan karir karyawan secara langsung memberikan pengaruh positif terhadap kinerja karyawan, yang artinya kinerja karyawan secara tidak langsung juga mempengaruhi efektivitas perusahaan. Hasil penelitian yang dilakukan oleh Caroline \& Susan (2015) menunjukkan bahwa kemajuan karir berpengaruh secara positif dan signifikan terhadap kinerja karyawan di Kenyatta University.

Penelitian dari Purwanis et al. (2014) dengan judul Pengaruh Pengembangan karir, Promosi Jabatan, Karakteristik Pekerjaan dan Motivasi Berpretasi Terhadap Kinerja Pegawai Dinas Kesehatan Kabupaten Kerinci. Penelitian tersebut menyatakan Pengembangan karir berpengaruh positif signifikan terhadap kinerja pegawai Dinas Kesehatan Kabupaten Kerinci. Kartika Dewi Adyarta, Suharnomo, Dalam penelitian Umar (2015) berpendapat bahwa pengembangan karir berpengaruh positif siginifikan terhadap kinerja karyawan.

Hal ini didukung oleh pendapat Mukhlis (2016) yang menyatakan bahwa pengembangan karir berpengaruh positif dan signifikan terhadap kinerja karyawan.

Berdasarkan hasil analisis pengaruh Motivasi Kerja terhadap Kinerja Karyawan diperoleh nilai Signifikansi sebesar 0,000 dengan nilai koefisien beta 0,563 bernilai positif. Nilai Signifikansi $0,000<0,05$ mengindikasikan bahwa $\mathrm{H}_{0}$ ditolak dan $\mathrm{H}_{3}$ diterima. Hasil ini mempunyai arti bahwa Motivasi Kerja berpengaruh positif terhadap Kinerja Karyawan. Hal ini menandakan semakin tinggi Motivasi Kerja maka Kinerja Karyawan akan semakin meningkat, begitu juga sebaliknya.

Hasil penelitian yang dilakukan oleh Zameer et al. (2014) menunjukkan bahwa motivasi secara signifikan mempengaruhi kinerja karyawan di industri minuman Pakistan. Penelitian Charity (2015) juga mengemukakan bahwa pengembangan kair berpengaruh positif dan signifikan terhadap kinerja karyawan. Takahashi (2006) penelitian menunjukkan bahwa motivasi berpengaruh positif terhadap kinerja karyawan. Motivasi kerja memiliki pengaruh positif dansignifikan terhadap kinerja karyawan Elqadri et al. (2015). Motivasi kerja yang tinggi akan mampu membuat kinerja karyawan menjadi meningkat. penelitian yang dilakukan oleh Amalia \& Fakhri (2016) bahwa motivasi kerja mempengaruhi kinerja karyawan.

Berdasarkan hasil analisis data didapat nilai Z hitung sebesar 3,451 > 1,96. Artinya Motivasi Kerja mediasi hubungan antara Pengembangan Karir terhadap Kinerja Karyawan. Selain itu, nilai VAF sebesar 29,2\% yaitu lebih dari 20\%, maka dapat dijelaskan bahwa ada efek mediasi atau dengan kata lain Motivasi Kerja sebagai pemediasi parsial (partial mediation). Pengembangan karir sangat berpengaruh terhadap motivasi kerja karyawan. Semakin baik pengembangan karir yang dimilik semakin tinggi motivasi kerja karyawan tersebut. Meningkatkan motivasi kerja akan membuat kinerja karyawan semakin meningkat. Namum ketika karyawan memilik pengembangan karir yang rendah, hal ini akan berpengaruh terhadap motivasi kerja yang dirasakan karyawan. Semakin menurunnya motivasi kerja menyebabkan kinerja karyawan dalam perusahaan akan memburuk. 
Mengacu pada hipotesis-hipotesis yang telah ditarik pada $\mathrm{H}_{1}, \mathrm{H}_{2}$, dan $\mathrm{H}_{3}$ dengan menggunakan penelitian sebelumnya sebagai acuan dalam penarikan hipotesis terdapat hubungan yang saling mempengaruhi antar variabel pengembangan karir, motivasi kerja dan kinerja karyawan.

Penelitian yang dilakukan oleh Umar (2015) mengenai pengaruh pengembangan karir terhadap kinerja karyawan melalui mediasi motivasi kerja mendapat hasil bahwa motivasi kerja dapat memediasi pengaruh pengembangan karir terhadap kinerja karyawan. Penelitian yang dilakukan oleh Dewi \& Utama (2016) bahwa motivasi kerja dapat memediasi pengaruh pengembangan karir terhadap kinerja karyawan. semakin baik pengembangan karir karyawan dan semakin baik pula kinerja karyawan.

Penelitian yang dilakukan oleh Sari \& Sriathi (2019) menyatakan Motivasi kerja berpengaruh dan signifikan terhadap kinerja karyawan serta mampu memediasi pengaruh pengembangan karir terhadap kinerja karyawan.

Hasil penelitian ini memiliki implikasi teoritis dan praktis. Secara teoritis, hasil penelitian ini menunjukan bahwa pengembangan karir dan motivasi kerja berpengaruh poitif dan signifikan terhadap kinerja kaeyawan. Dengan demikian, hasil penelitian ini memberi dukungan empiris dan dapat dinyatakan memperkuat hasil-hasil studi terdahulu. Secara praktis, penelitian ini diharapkan dapat memberikan manfaat bagi pemimpin dan karyawan di BPR Lestari Cabang sesetan Denpasar. Pihak manajemen dan karyawan diharapkan dapat meningkatkan kinerja karyawan dalam perusahaan guna dapat meningkatkan hasil kerja yang lebih efektif dan efisien.

\section{SIMPULAN}

Pengembangan Karir berpengaruh positif terhadap Kinerja Karyawan. Hal ini menunjukan bahwa jika Pengembangan Karir semakin meningkat maka Kinerja Karyawan akan meningkat pula. Pengembangan Karir berpengaruh positif terhadap Motivasi Kerja. Hal ini menunjukan bahwa jika Pengembangan Karir semakin meningkat maka akan meningkatkan pula Motivasi Kerja. Motivasi Kerja berpengaruh positif dan signifikan terhadap Kinerja Karyawan. Hal ini menunjukan bahwa jika Motivasi Kerja semakin meningkat maka akan meningkatkan pula Kinerja Karyawan. Motivasi Kerja memediasi pengaruh Pengembangan Karir terhadap Kinerja Karyawan. Hal ini menunjukan bahwa Pengembangan Karir memberikan dampak yang signifikan terhadap Kinerja Karyawan jika di mediasi oleh Motivasi Kerja, yang berarti bahwa Kinerja Karyawan sangat tergantung pada tingkat Motivasi Kerja tersebut dan juga tingkat Pengembangan Karir.

Perusahaan harus memberikan informasi yang jelas kepada setiap karyawan perihal kegiatan yang dapat mengembangkan karir karyawan pada perusahaan, dan perusahaan bisa membuat akun media sosial agar semua karyawan mengetahui informasi pengembangan karir yang dampaknya pada peningkatan kinerja karyawan itu sendiri. Perusahaan hendaknya memberikan jaminan kesehatan yang layak bagi karyawannya sehingga karyawan akan lebih termotivasi dalam bekerja dan merasa terjamin dari segi kesehatan. Karyawan diharapkan mematuhi perintah 
yang diberikan oleh atasan, sehingga terjalin hubungan baik antara karyawan dan atasan itu sendiri, dengan demikian kinerja karyawan akan lebih dapat dipantau oleh atasan. Perusahaan BPR Lestari Cabang Sesetan Denpasar harus tetap mempertahankan pengembangan karir di dalam perusahaan agar karyawan merasa terdorong dalam meningkatkan semangat dalam bekerja, sehingga akan meningkatkan kinerja karyawan BPR Lestari Cabang Sesetan Denpasar. Selain itu, atasan perlu memberikan dukungan kepada karyawan mengenai pengembangan karir dan memotivasi karyawan agar dapat mengembangkan karirnya diperusahaan dan perusahaan memberikan aturan kepada karyawan dalam bekerja agar mereka bisa selalu menaati peraturan yang ditetapkan oleh perusahaan.

\section{REFERENSI}

Amalia, S., \& Fakhri, M. (2016). Pengaruh Motivasi Kerja Terhadap Kinerja Karyawan Pada PT. Gramedia Asri Media Cabang Emerald Bintaro. Jurnal Computech \& Bisnis, 10(2), 119-127.

Ardana, I. K., Mujiati, N. W., \& Utama, I. W. M. (2012). Manajemen Sumber Daya Manusia. Edisi Pertama. Yogyakarta: Graha Ilmu.

Balbed, A., \& Sintaasih, D. K. (2019). Pengaruh Pengembangan Karir Terhadap Kinerja Karyawan Melalui Pemdiasi Motivasi Kerja Karyawan. E-Jurnal Manajemen, 8(7), 4676-4703. https://doi.org/https://doi.org/10.24843/EJMUNUD.2019.v08.i07.p24

Bianca, A., Katili, P. B., \& Anggraeni, S. K. (2014). Pengaruh Motivasi, Pengembangan Karir, dan Kepuasan Kerja Terhadap Kinerja Karyawan dengan Metode Structural Equation Modelling. Jurnal Teknik Industri, 2(3), 334-340.

Retrieved

from http://jurnal.untirta.ac.id/index.php/jti/article/view/2302

Caroline, O., \& Susan, W. (2015). Influence of Career Development on Employee Performance in the Public University, a Case of Kenyatta University. International Journal of Social Sciences Management and Entrepreneurship, 1(2), 1-16. https://doi.org/10.1017/CBO9781107415324.004

Charity, B. C. (2015). Effect of Training and Career Development on Employee Performance: a Case of Kcb Branches in the North Rift Region, Kenya. International Journal of Advanced Research in Management and Social Sciences, 4(5), 2278-6236.

Dewi, N. L. P. A. A., \& Utama, I. W. M. (2016). Pengaruh Pengembangan Karir Terhadap Kinerja Karyawan Melalui Mediasi Motivasi Kerja Pada Karya Mas Art Gallery. E-Jurnal Manajemen Universitas Udayana, 5(9), 494-5523.

Elqadri, Z. M., Priyono, P., Suci, R. P., \& Chandra, T. (2015). Effect of Leadership 
Style, Motivation, and Giving Incentives on the Performance of EmployeesPT. Kurnia Wijaya Various Industries. International Education Studies, 8(10), 1913-1920. https://doi.org/10.5539/ies.v8n10p183

Flippo, E. B. (2009). Manajemen Personalia. Jakarta: PT. Gelora Aksara Pratama.

Hakim, R. B. (2014). Manajemen dan Evaluasi Kinerja Karyawan (First Edit). Jakarta: Aswaja Pressindo.

Kaseger, R. (2013). Pengembangan Karir Dan Self-Efficacy Terhadap Kinerja Karyawan Pada Pt. Matahari Department Store Manado Town Square. Jurnal Riset Ekonomi, Manajemen, Bisnis Dan Akuntansi.

Lisdiani, V., \& Ngatno. (2017). Pengaruh Pengembangan Karir terhadap Kepuasan Kerja Karyawan Melalui Motivasi Kerja Sebagai Variabel Intervening (Studi Kasus Pada Hotel Grasia Semarang). Diponegoro Journal of Social and Political Sciencet, 6(4), 105-112.

Mukhlis, D. (2016). Pengaruh Perkembangan Karir dan Kinerja Karyawan. Jurnal Lembaga Keuangan Dan Perbankan, 1(1).

Nurcahyani, N. M., \& Adnyani, I. G. A. D. (2016). Pengaruh Kompensasi Dan Motivasi Terhadap Kinerja Karyawan Dengan Kepuasan Kerja Sebagai Variabel Intervening. E-Jurnal Manajemen Universitas Udayana, 5(1), 500532.

Purwanis, Sulastri, \& Rozani, A. (2014). Pengaruh Pengembangan Karier, Promosi Jabatan, Karakteristik Pekerjaan Dan Motivasi Berprestasi Terhadap Kinerja Pegawai Dinas Kesehatan Kabupaten Kerinci. Jurnal Program Pascasarjana, 4(2). Retrieved from http://ejurnal.bunghatta.ac.id/index.php?journal=JPSC2\&page=article\&op=v iew\&path\%5B $\% 5 \mathrm{D}=3109$

Sari, N. N. (2016). Pengaruh Pengembangan Karir Terhadap Kinerja Karyawan Pt Pln ( Persero ) Wilayah Kalimantan Utara Sektor Pembangkit Mahakam Samarinda. EJournal Administrasi Bisnis, 4(2), 620-630.

Sari, N. P. S. K., \& Sriathi, A. . A. (2019). Peran Motivasi Kerja Memediasi Pengaruh Pengembangan Karir Terhadap Kinerja Karyawan Fairmont Sanur Beach Hotel. E-Jurnal Manajemen Universitas Udayana, 8(8), 4788-4814. https://doi.org/10.24843/ejmunud.2019.v08.i08.p03

Shahzadi, I., Javed, A., Pirzada, S. S., Nasreen, S., \& Khanam, F. (2014). Impact of Employee Motivation on Employee Performance. European Journal of Business and Management, 6(23), 159-167. 
Sungkono, P. (2013). Pengaruh Pengembangan Karir Terhadap Motivasi Kerja Karyawan Pada PT. Excel Utama Indonesia Karawang. Jurnal Manajemen, 10(3), 1124-1134.

Takahashi, K. (2006). Effects of wage and promotion incentives on the motivation levels of Japanese employees. Career Development International, 11(3), 193203. https://doi.org/10.1108/13620430610661722

Umar, A. (2015). The Effect Of Motivation And Career Development Against Employees Performance And Job Satisfaction Of The Governor Office South Sulawesi Province, Indonesia. International Journal of Management Sciences, 5(9), 628-638. https://doi.org/RePEc:rss:jnljms:v5i9p3

Venny Ferari Veronica, Swasto, B., \& Mukzam, M. D. (2018). Pengaruh Insentif Karyawan Terhadap Kinerja Karyawan Dengan Variabel Mediator Motivasi Kerja (Studi pada Karyawan Bagian Pabrikasi PG Kebon Agung Malang). Jurnal Administrasi Bisnis, 55(2), 139-145. Retrieved from http://administrasibisnis.studentjournal.ub.ac.id/index.php/jab/article/view/22 81

Zameer, H., Alireza, S., Nisar, W., \& Amir, M. (2014). The Impact of the Motivation on the Employeeâs Performance in Beverage Industry of Pakistan. International Journal of Academic Research in Accounting, Finance and Management Sciences, 4(1), 293-298. https://doi.org/10.6007/ijarafms/v4$\mathrm{i} 1 / 630$ 